\title{
Mike Aling
}

Title of Work: Digital Cottage Industries

Architectural film work exhibited in the

'Experiment 01 - 60 Second Architecture' exhibition

+ filmed interview of Mike Aling discussing project displayed

\section{Location:}

DDP (Dongdaemoon Design Plaza) Gallery Moon

Seoul, Korea, 6- 27 June 2015

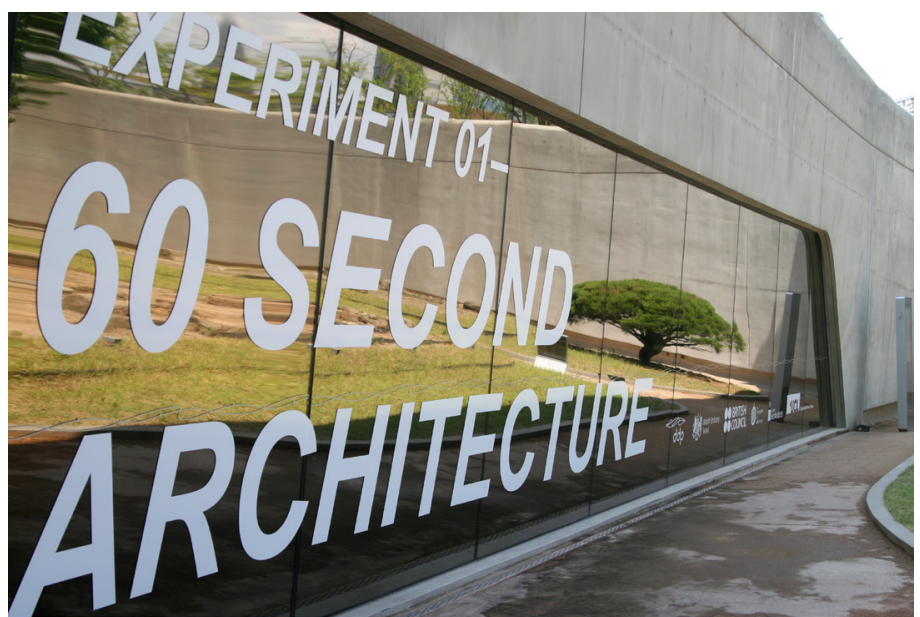

DDP entrance

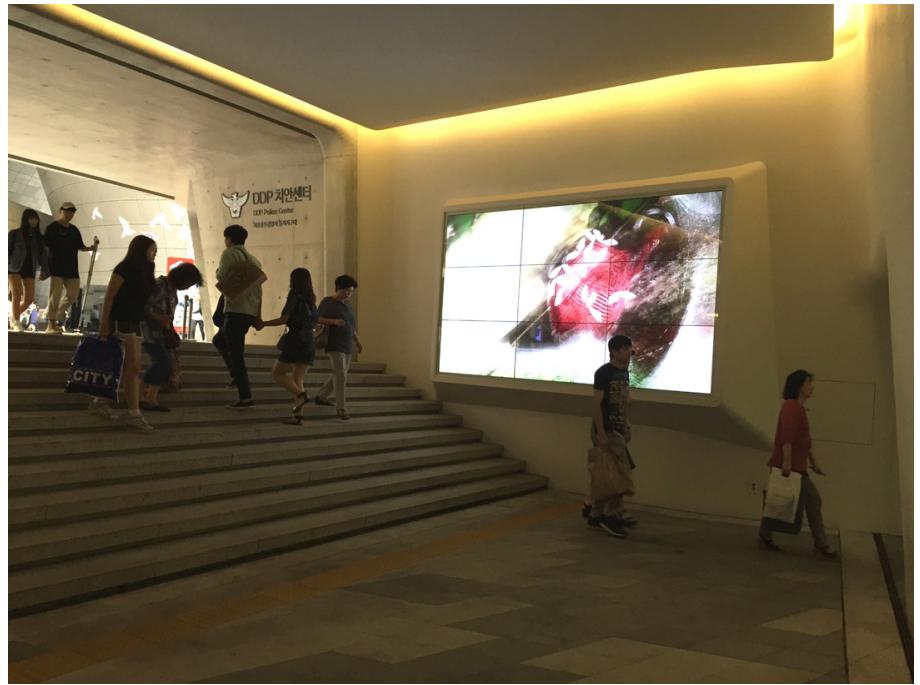

Mike Aling film work displayed in entrance foyer

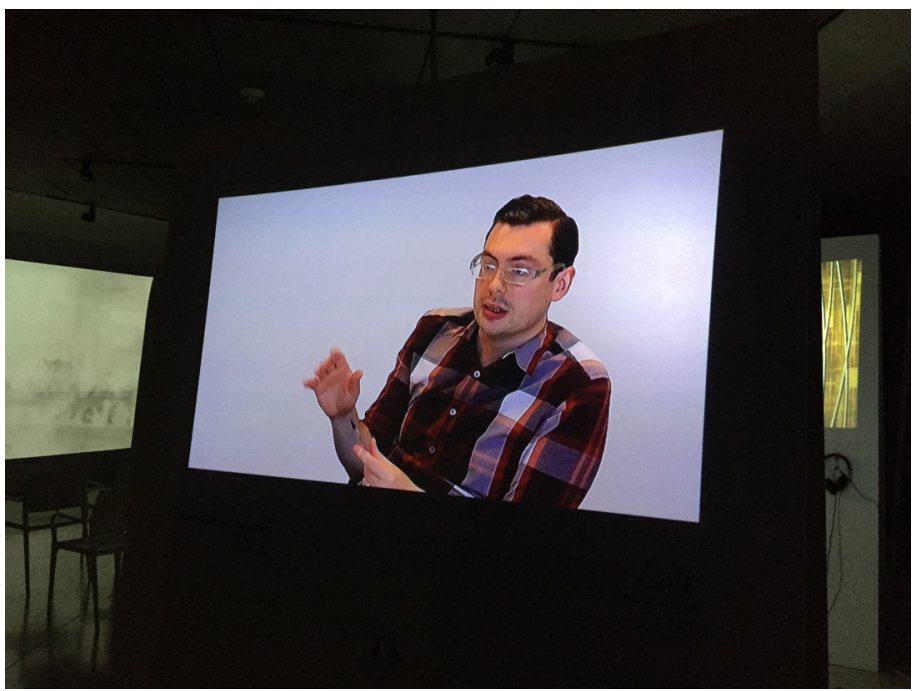

Mike Aling interview + film work displayed in Moon Gallery, DDP 


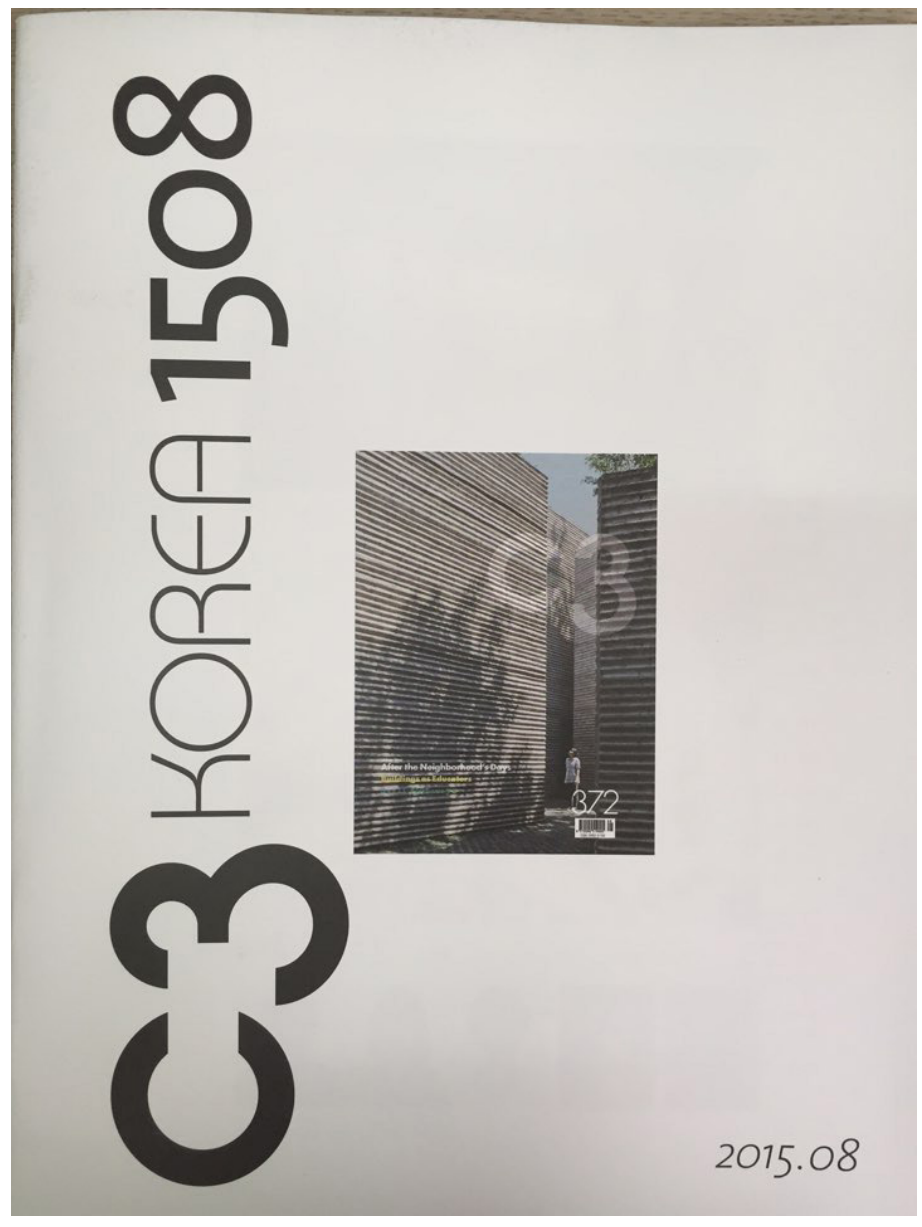

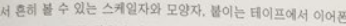

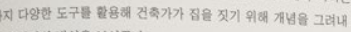
늘 저마다의 방식을 보어준다.

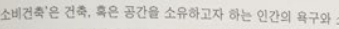

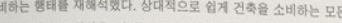

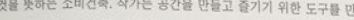
댐어 사용자가 '건축'을 손십게 경혐하고 소배할 수 있는 아이디어 [5제세시합다.

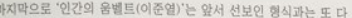

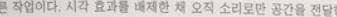

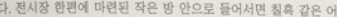
이 기다리고 인다. 오직 소리어만 의존화야 함ㅁㄹㅗ 눈요 강아반다.

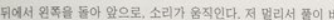

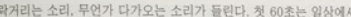

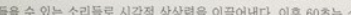

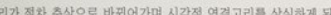

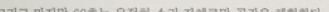

대부분의 건혁 전시는 섬명젹이기 마련이다. 룰람객은 도뫼과 사장.

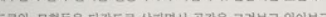

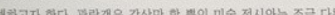
प.

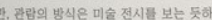
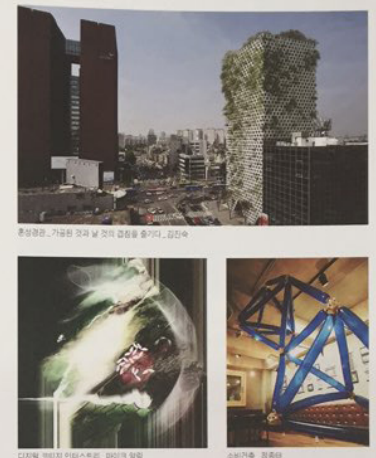

건추, 만인의 품으로

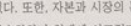

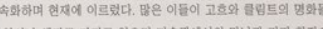

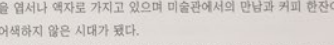

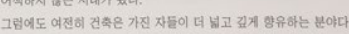

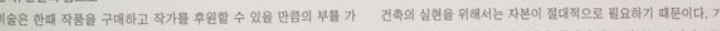
(1) The

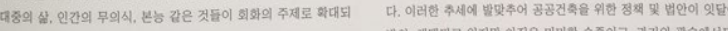

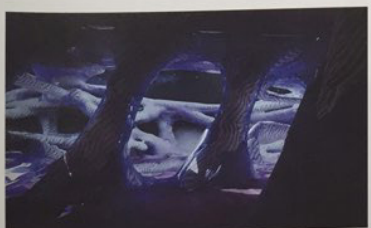

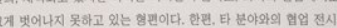

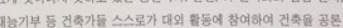

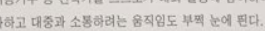

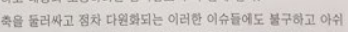

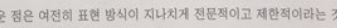

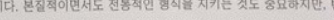

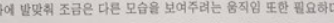

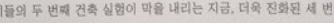

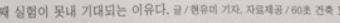

This page:

Work from exhibition featured in Korean Design magazine 'C3'

\section{Overleaf:}

Invitation to exhibition $+$

Exhibition catalogue with project images and synopsis featured 



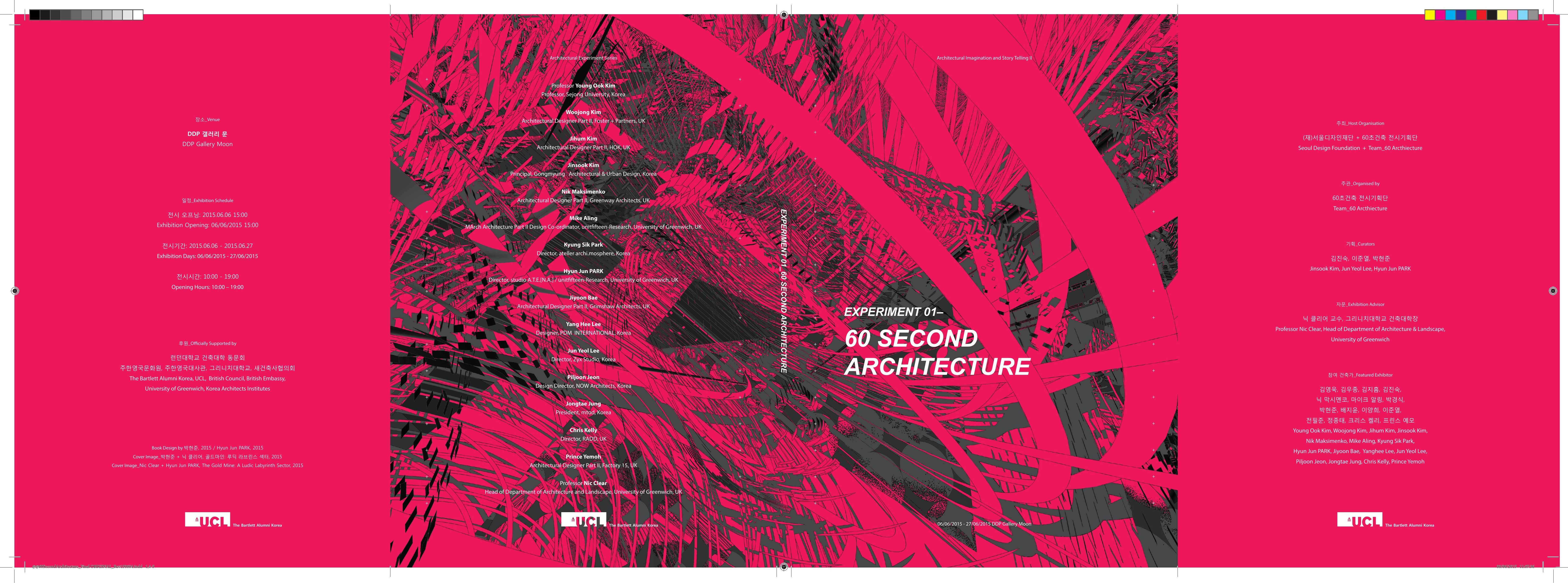




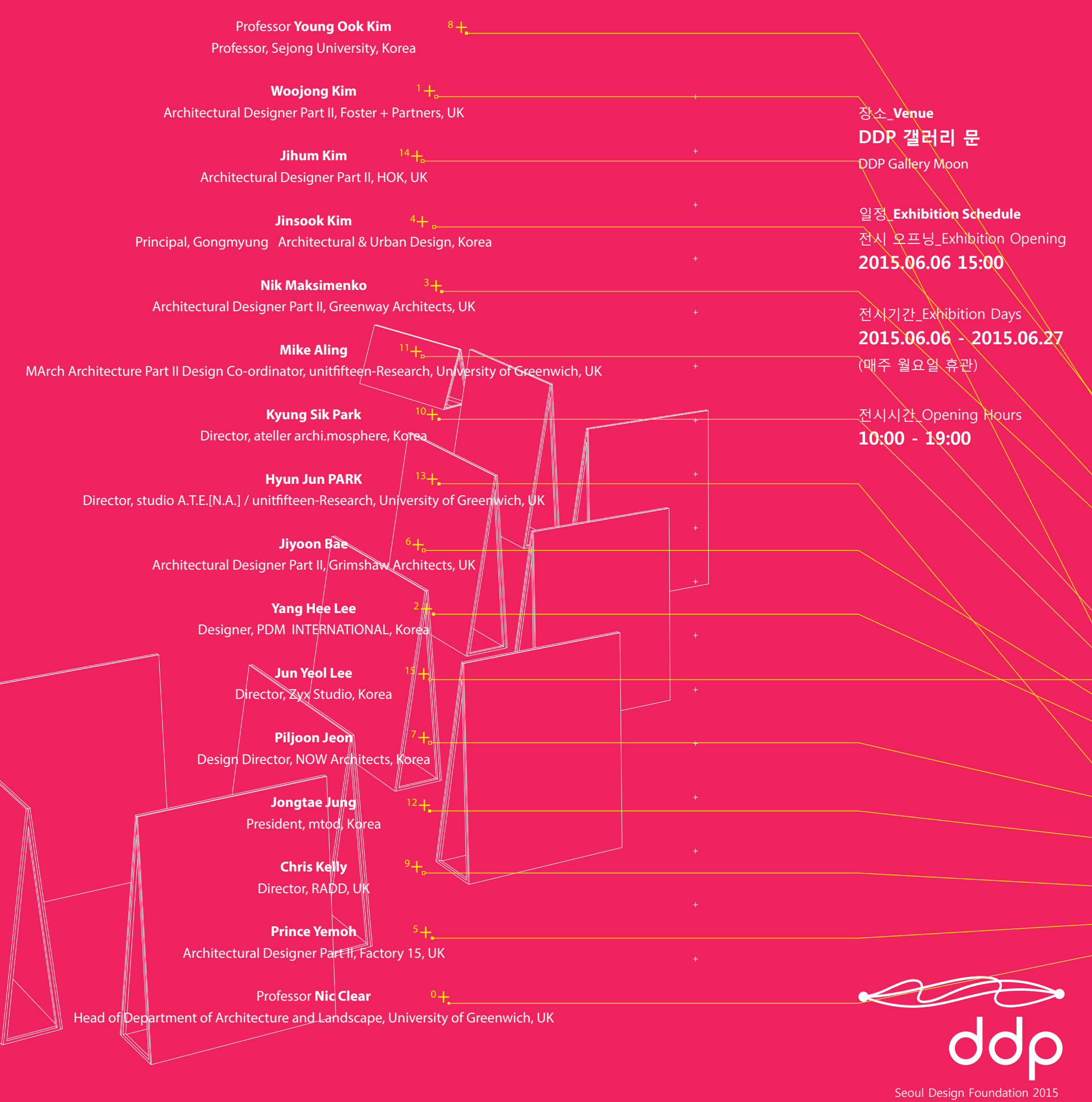

기획_Curators

김진숙 + 이준열 + 박현준

Jinsook Kim + Jun Yeol Lee + Hyun Jun PARK

자문_Exhibition Advisor

닉 클리어 교수, 그리니치 대학교 건축대학장

Nic Clear

Head of Department of Architecture \& Landscape

University of Greenwich
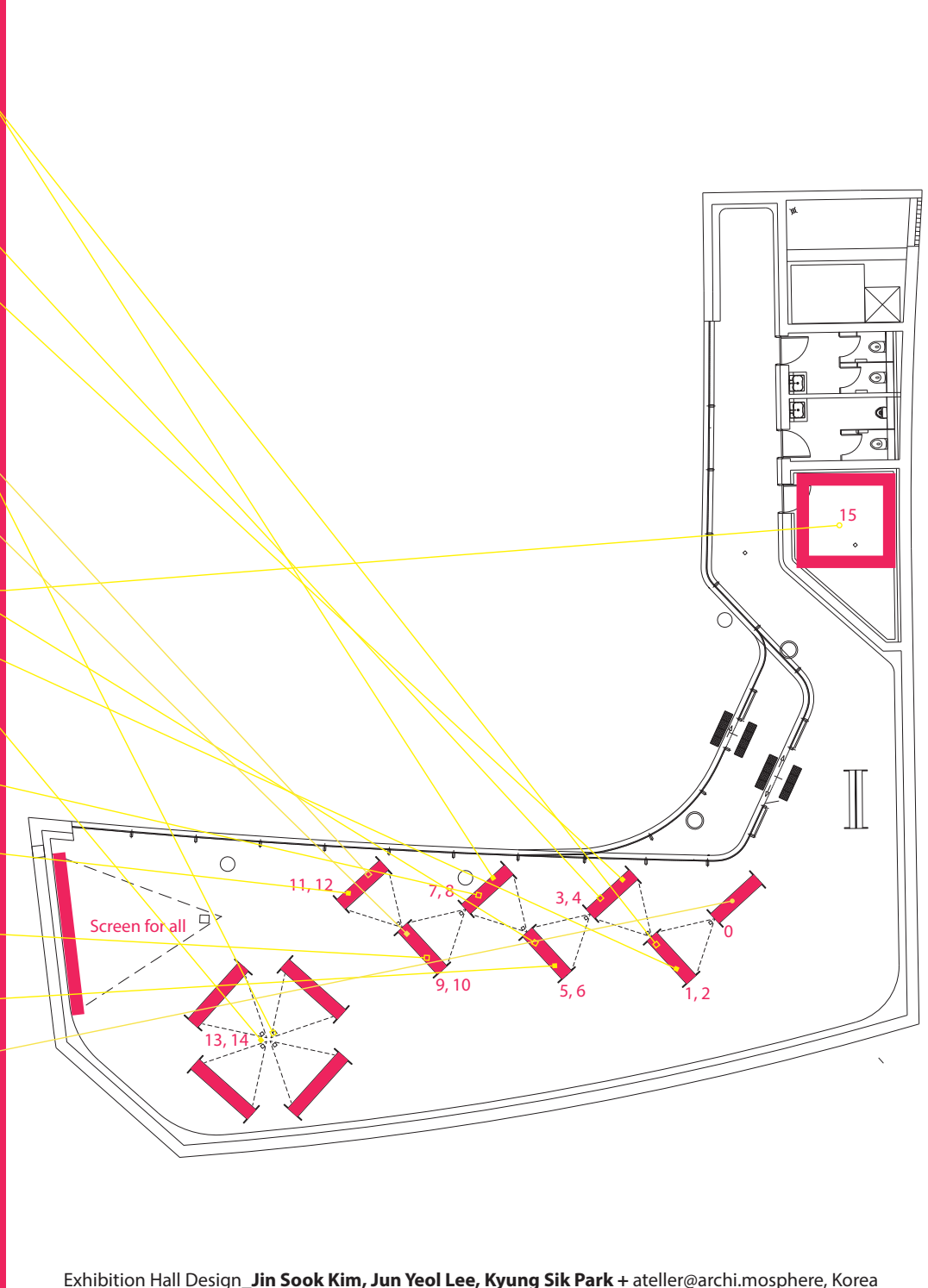


\section{Digital Cottage Industries}

디지털 코티지 인더스트리

\section{Mike Aling}

The future of cities will consist of two different modalities combined within the ageographical and largely unrecognized meta city that is the internet. -William Gibson [1]

The spectra of digital communications, from mobile phones to the internet to emerging technologies in virtuality is allowing for a renaissance in cotage industres, in that an increasing number of products (digital or otherwise) floating on the pervasive digital-market are developed and distributed from the home. In an age of globalized networks, the Digital Cottage Industries project posits small scale architectures in order to resuscitate a sense of community akin to how traditional cottage industries functioned, principally through digital industry geographical proximity and human contact.

A couple's retreat, a credit union, an open source software pavilion, a mobile library, a parcel distribution centre, a digital tool supplier, a home for an online educator and a wedding venue. The project develops a number of small scale digital-inposited into a series of sites developed from reseach into fims exploring the UK rural landscape.

Digital Cottage Industries is a short film composed from a number of digital paintings, each an isometric model constructed to form a 4-dimensional moving isometric image. Isometry is used as a representational tactic in the work in order to draw equivalences between each site depicted and each architecture posited.

My work is cognisant of media theorist Lev Manovich's proclamation that digital cinema is akin to a type of digital painting [2], therefore siting this project between architecture and digital painting. Ultimately, the intention is that the work represents ubiquity, in opposition to the perspectival scopic regime that cannot help but compartmentalise our vision of the world.

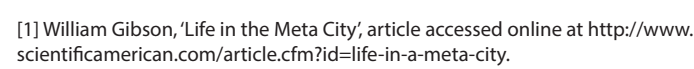

미래의 도시는 물리적인 도시 그 자체와 보이지 않지만 거대한 메타 시티인 인터넷, 이 두 가지 다른 양상으로 존재할 것이다.

\section{윌리엄 김슨 [1]}

휴대전화에서부터 복합적인 기술로 이루어진 인터넷까지, 완전한 가상 공간으로부터 증강현실에 이르기까지 디지털 커뮤니케이션이 보여주는 다양한 스펙트럼은, 주택산업의 르네상스를 가져왔다. 이 결과 오늘날 여러가지 다양한 형 태의 디지털 기기들은 시장에서 가정집에 이르기까지 널리 퍼져있다. 디지털 테크놀러지에 기반한 디지털 코티지 인떠 스트리는 기존에 존재하던 가내 공업의 기능을 다시 살려 낸다. 디지털 산업의 기본적인 원칙은 위치에 구애받지 않 는 사람들간의 의사소통이다.

커플의 여행, 신용조합, 오픈소스 소프트웨어 공간, 이동식 도서관, 소포 분산 센터, 가상의 툴 제공자, 온라인 교육공 간, 그리고 결혼식장. 이 프로젝트는 여러가시 작은 규모의 가상의 산업건축물을 개발하고 이를 가상의 공간으로 엮는 다. 영화의 배경은 형국의 시콜시역이다. 건축물들은 부드 에 계회ㄷㅚㅚ 딱딱한 그칙들에서 자유롬게 한다.

이 작품은 일련의 디지털 페인팅을 아이소매트릭 모델을 이용하여 4 차원적으로 움직이는 공간을 짧은 영화로 구성 한 작품이다. 아이소메트릭기법은 각기 건축물의 위치와 장 소를 동시에 잘 묘사할수있는 건축적 표현기법의 한 가지 종류이다.

이 작업은 Lev Manovich가 언급한 디지털 영화는 가상의 그림과도 같은 것이라는 설명에서 출발하며, 건축과 디지 털 페인팅의 간극에 놓인다. [2] 이 작업을 통해 궁극적으 로 표현하고자하는 편재성, 즉 언제 어디서나 존재 가능함 에 대한 물음은 체제를 바라보는 우리의 방대한 시각에 반 하여 보다 좁고 분할된 관점으로 세계를 바라보지 않을 수 없게 한다.

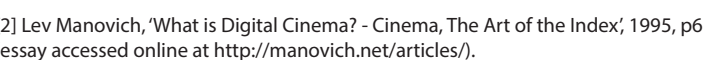

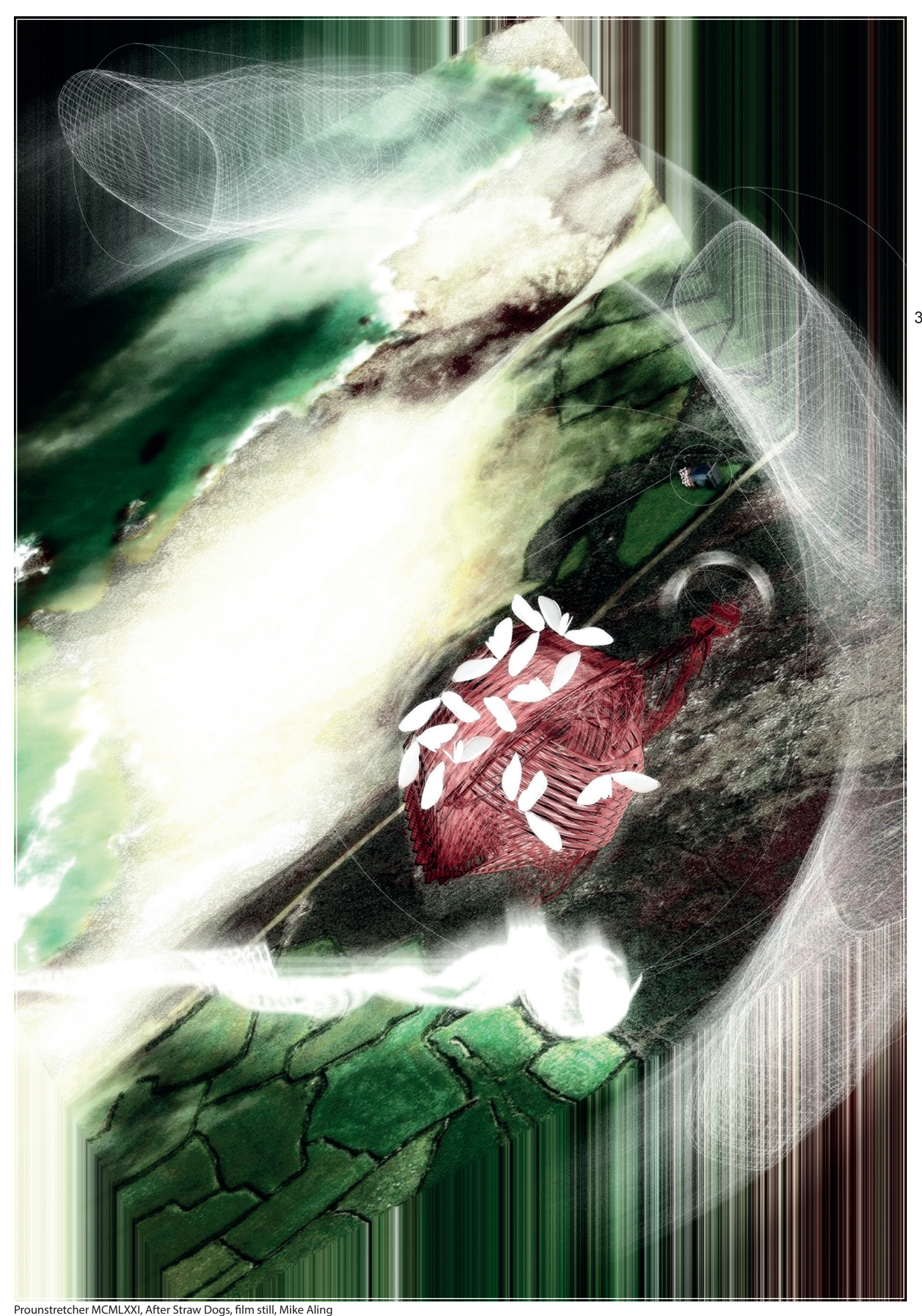

Experiment 01_60 Second Architecture 

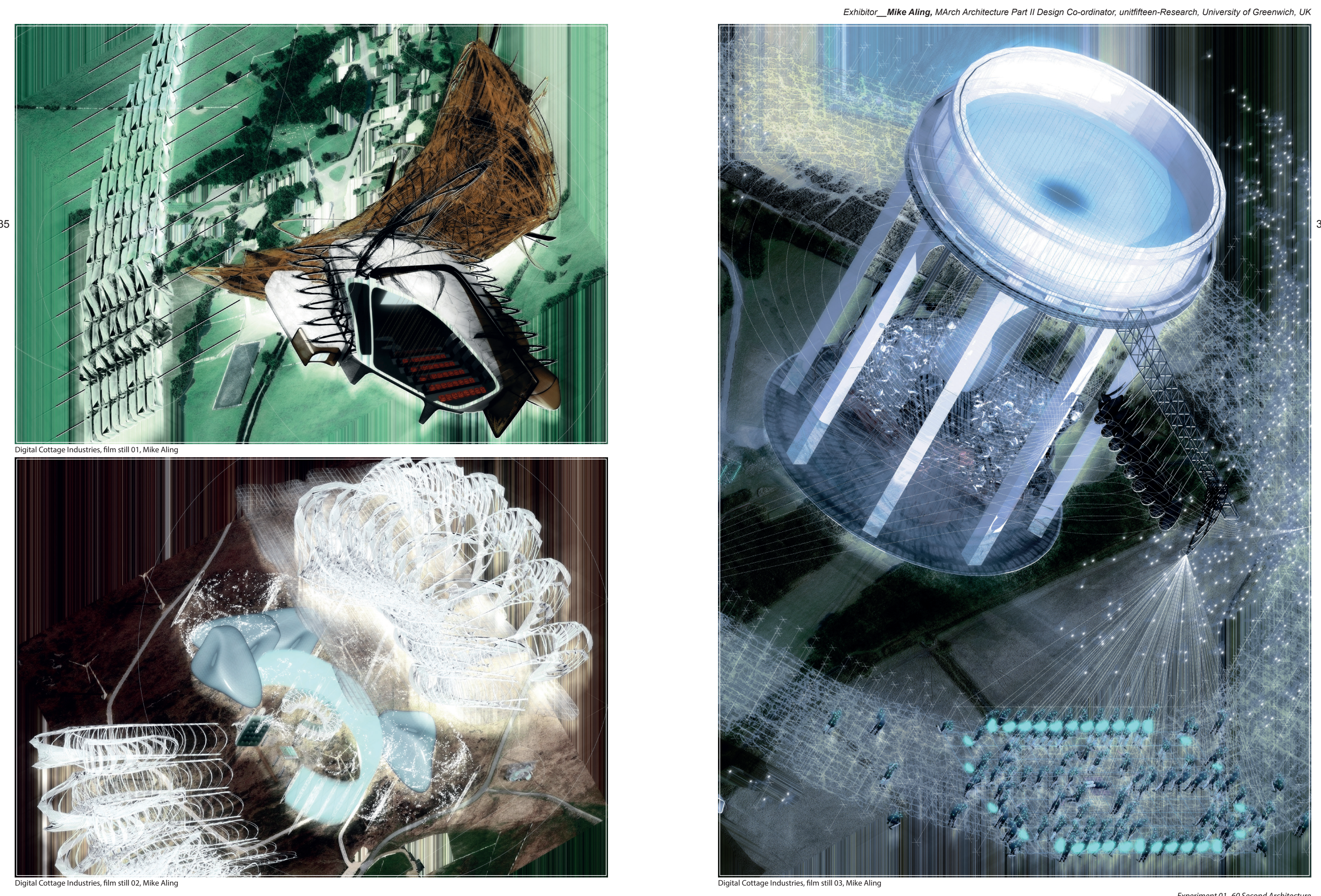


\section{$\underset{d d p}{2}$}

73

British Embassy
Seoul

88 BopTISH

the
UNIVERSITY
of
GREENWICH

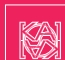

새겁축 사혈의회
Any copy of this book issued by the publisher as a paperback is sold be lent resald hired out or otherwise circulted withe the pulle er's prior consent in any form of binding or cover other then thet which it is published and without a similar condition including these words being imposed on a subsequent purchase.

First published in the United Kingdom
in 2015 by The Bartlett Alumni Korea, UC: in 2015 by The Bartiett Alumni Kore Creek Road, Greenwich, London

SE8 3BU

Copyright $\odot 2015$ Editor and Contributors [Young Ook Kim, Woojong 74 Kim, Jihum Kim, Jinsook Kim, Nik Maksimenko, Mike Aling, Kyung

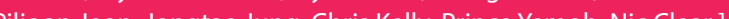

@ 2015 The Bartlett Alumni Korea, UCL

All Rights Reserved.

No part of this publication may be reproduced or tramsmitted in an

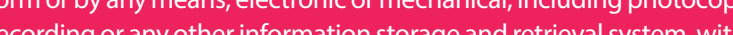
out prior permission in writing from the publisher.

British Library Cataloguing-inn-Publication Data.
A catalogue record for this book is available from the British Library.

ISBN 978-0-9933109-0-4

Edited by Hyun Jun PARK

Book Design and Layout by Hyun Jun PARK

Introduction by Nic Clear

Woojong Kim, Jihum Kim

Cover Image:

The Gold Mine_A Ludic Labyrinth Sector
by Hyun Jun PARK and Nic Clear 2015

Printed and bound in South Korea in 2015

GSUNGTECH Co. LtD.

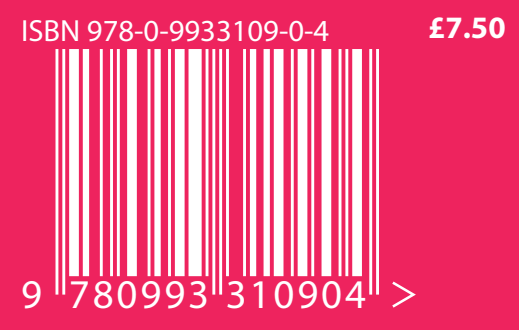

